The University of San Francisco

USF Scholarship: a digital repository @ Gleeson Library |

Geschke Center

Philosophy

College of Arts and Sciences

1997

\title{
Double-Effect and the Ethical Significance of Distinct Volitional States
}

Thomas A. Cavanaugh

University of San Francisco, cavanaught@usfca.edu

Follow this and additional works at: http://repository.usfca.edu/phil

Part of the Philosophy Commons

\section{Recommended Citation}

Cavanaugh, Thomas A., "Double-Effect and the Ethical Significance of Distinct Volitional States" (1997). Philosophy. Paper 30.

http://repository.usfca.edu/phil/30

This Article is brought to you for free and open access by the College of Arts and Sciences at USF Scholarship: a digital repository @ Gleeson Library | Geschke Center. It has been accepted for inclusion in Philosophy by an authorized administrator of USF Scholarship: a digital repository @ Gleeson

Library | Geschke Center. For more information, please contact repository@usfca.edu. 


\section{T. A. Cavanaugh, Philosophy, University of San Francisco \\ Penultimate draft of: Double-Effect and the Ethical Significance of Distinct Volitional States, Journal of Christian Bioethics, Vol. 3, 1997, pp. 131-141.}

\section{Double Effect and the Ethical Significance of Distinct Volitional States}

Those who employ double-effect reasoning (DER) ${ }^{\mathrm{i}}$ hold that the intended/foreseen distinction (henceforth the $\mathrm{i} / \mathrm{f}$ distinction) between what one causes with intention and what one causes with foresight but without intention has ethical relevance. ${ }^{\mathrm{ii}}$ In what follows, I argue for the ethical relevance of this distinction. First, I locate the distinction within double-effect reasoning (DER); second, I present and reject a number of interpretations of its ethical relevance; third, and finally, I argue for its ethical relevance.

\section{Double-Effect Reasoning (DER)}

A non-consequentialist employs DER to analyze an otherwise good action that causes foreseen harm the causing of which is, on the face of things, not ethically in the clear. One uses DER already convinced that: the act would be good if the foreseen harm were not inseparable from or likely to attend it; the foreseen harm is likely to attend the act; and, finally, the act is the least harmful action by which to realize the good at issue. ${ }^{\mathrm{iii}}$ Thus, DER is a non-consequentialist analysis of actions that would be good and ethically in the clear but for the harm associated with them. Using DER one attempts to determine if such an action is justifiable.

DER theorists consider acts such as tactical bombing that foreseeably harms non-combatants, death-causing palliative analgesic administration to a terminally ill patient, and the surgical removal

of a life-threatening cancerous gravid uterus when the fetus is not viable. ${ }^{\text {iv }}$ Thinkers contrast these acts with terror bombing, voluntary active euthanasia, and craniotomy during pathological labor to save the mother's life. For example, DER theorists argue that in a just war there is an absolute (or a 
great) ethical presumption against terror bombing while tactical bombing in which foreseeably but not intentionally one harms noncombatants can be justified (or more easily justified than terror bombing) -- if it meets the conditions set forth in DER. ${ }^{\mathrm{v}}$ These theorists assert that this is the case even when terror and tactical bombing cause harm of the same magnitude with the same probability.

DER partially depends on the i/f distinction. ${ }^{\text {vi }}$ One who employs DER makes three specific claims about this distinction. First, that there is a distinction between the intended and the foreseen. Second, that this distinction applies to the contrasted cases in such a way as to categorize, for example, death in voluntary active euthanasia which comes about from a lethal injection of carbon monoxide as intended while holding that the death of a terminally ill patient caused by palliative morphine administration is foreseen but not intended. Third, one who uses DER holds that the distinction has ethical significance. I argue for the ethical import of this distinction. Before doing so, I consider a number of interpretations of its ethical significance which I understand to be mistaken.

\section{The Ethical Relevance of the I/F Distinction: What It Is Not}

One opponent of DER, H.L.A. Hart, understands proponents of DER to use the $\mathrm{i} / \mathrm{f}$ distinction to mark a difference in the probability of intended and foreseen consequences. Speaking of a craniotomy and the removal of a cancerous gravid uterus -- both of which result in the death of a fetus -- he says:

[I]f the craniotomy is contrasted with the removal of the womb containing the foetus as a case of "direct" killing it must be on the basis that the death of the foetus is not merely contingently connected with craniotomy as it is with the removal of the womb containing it. But it is not clear that the supposition of the survival of the foetus makes better sense in the one case than in the other. (Hart, 1967, p. 13)

By "contingent" Hart means not causally or nomologically necessary. The death would be contingent 
if, according to the physical and biological laws obtaining, it were possible for the foetus to live. According to Hart, if the $\mathrm{i} / \mathrm{f}$ distinction has significance, it must be insofar as it marks a difference between what is and what is not nomologically necessary. As Hart notes, however, if the fetus is not viable and one removes the uterus, the fetus will die with nomological necessity. It is no more nomologically possible for a non-viable fetus to live when the uterus has been surgically removed from the mother than it is for a fetus to live when its head has been crushed. Yet, historically, those who apply DER to the hysterectomy case employ it in cases when the fetus is nomologically certain to die if the uterus is removed from the woman's body. Accordingly, the advocates of the $\mathrm{i} / \mathrm{f}$ distinction do not understand it to have ethical relevance insofar as it marks or coincides with a difference in the probability of the harms.

Nonetheless, as Judith Lichtenberg notes, the i/f distinction may coincide with a difference in the probability of the harms coming about. She says:

$[1] \mathrm{t}$ is not the mere difference between intending and not intending that makes the moral difference. But one might nevertheless think that in general this difference is correlated with other relevant factors. At the very least, one is in general less likely to kill civilians if one is not trying to kill them. (Lichtenberg, 1994, p. 360, original emphasis)

Lichtenberg holds that although the $\mathrm{i} / \mathrm{f}$ distinction itself lacks ethical significance, it will often coincide with an ethically important difference, namely, the varying probabilities of the intended and foreseen consequences. ${ }^{\text {vii }}$ Such varying degrees of probability have ethical relevance because the less likely the harmful outcome, the more the action risks causing the outcome in contrast to causing it outright. $^{\text {viii }}$

Lichtenberg is correct. Often, foresight will be associated with risking harm in contrast to causing harm with the high or certain degree of probability characteristic of intentional harming. Nonetheless, I wish to argue the controverted and ultimately more interesting claim that the $\mathrm{i} / \mathrm{f}$ 
distinction itself has ethical relevance and thus has significance even in those cases in which one foresees that one will inevitably harm, cases such as death-causing palliative morphine administration and hysterectomy of a cancerous gravid uterus when the fetus is not viable. Before doing so, I will consider one more avenue for understanding the ethical relevance of the i/f distinction which I find mistaken.

One might think that the $\mathrm{i} / \mathrm{f}$ distinction's ethical relevance is to be found in its marking varying degrees of responsibility which agents have for causing harm intentionally or with foresight. ${ }^{\text {ix }}$ For example, Lichtenberg thinks that the $\mathrm{i} / \mathrm{f}$ distinction is proposed as marking an ethically relevant difference between, for example, the terror bomber's and the tactical bomber's varying degrees of responsibility for harming noncombatants. She understands proponents of DER to use the $\mathrm{i} / \mathrm{f}$ distinction to distinguish between the terror bomber's full responsibility and the tactical bomber's partial responsibility for harming non-combatants. This, however, is not correct. ${ }^{\mathrm{X}}$

If the terror or tactical bomber could claim not to have known about the harm to the non-combatants, or to have been overwhelmed by force, then neither would be fully responsible or even responsible at all for harming non-combatants. Such cases, however, are not those envisioned by the advocates of DER. Lichtenberg correctly notes that, as the cases are usually proposed, the terror and the tactical bombers both have full responsibility for the harm which comes to the noncombatants. Proponents of DER ask us to consider cases in which both the terror and the tactical bomber knowingly and without coercion cause the same harm to non-combatants with the same degree of probability. Insofar as an agent's responsibility for a consequence is established by the absence of force and his believing that the consequence would follow from his acting, there is no difference between the degree of responsibility which the terror and the tactical bombers have for harming non-combatants. If the $\mathrm{i} / \mathrm{f}$ distinction has ethical relevance, it will not be found in the varying degrees of responsibility which agents have for what they cause intentionally and what they cause with foresight but without intention. I will argue that the i/f distinction marks ethically important 
differences in the volitional states of agents.

\section{The Ethical Significance of the I/F Distinction}

The debate concerning the ethical import of the distinction focuses on actions that cause harms of the same magnitude with the same probability. ${ }^{\text {xi }}$ Specifically, the controversy concerns whether there is any ethical difference between an act in which harm is willed as a means and an act in which harm is willed as a concomitant insofar as the agent would rather cause the harm than forgo the realization of his end. There are a number of ways of articulating the ethical relevance of the $\mathrm{i} / \mathrm{f}$ distinction. I present what I take to be the most general and formal. ${ }^{\text {xii }}$ First, a short digression on what constitutes a human action is in order.

Human actions are a type of human causing. Human beings cause many things. For example, humans exert gravitational force on Jupiter. This, however, is not an action, for it is not up to us whether we exert this force. Yet, not all causings that are up to us are actions. For example, someone, wanting decaffeinated coffee, might pour regular coffee into a cup inculpably thinking that the coffee was decaffeinated. For something to be an action, the agent must know the relevant facts about what he causes. Nonetheless, not all knowing causings are actions. For example, if Alice throws Joe through a plate glass window, Joe may know what he causes as he hits the window and it shatters. Yet, he may not at all want to shatter the window. In order for a human causing to be a human action, the agent must cause willingly. ${ }^{\text {xiii }}$ A human action is a knowing willing causing or a voluntary causing. ${ }^{\text {xiv }}$ This is the essential characteristic of all human actions. The point is relatively non-controversial. Accordingly, I devote no further attention to it.

Jonathan Bennett, the most prominent opponent of the ethical import of the distinction says: The facts that make behavior wrong ... do not include any that concern the agent's state of mind (Bennett, 1995, p. 49).

By "the agent's state of mind" Bennett means the agent's beliefs and desires, what he thinks and 
wants. This position, however, is problematic. For, before determining what makes an action right or wrong, a prior question needs to be answered: what makes an action action? What distinguishes a nerve's twitching from a human's act, my twitching a nerve? Since knowing and willing make an action to be an action, why cannot they also, at least partially, make an action good or bad and better or worse?

Take an analogy. Say that a biologist defines a living organism as what can achieve homeostasis; the living is delimited from the non-living by being able to control or make an environment for itself. If the living is demarcated from the non-living by its ability to make or influence an environment, differences in this ability will make for differences within biology, for distinctions amongst living things. The general kinds of living things will be further classified in accordance with this property. It does not lie dormant, never again to be relied upon once it has done its initial job. If some animals have a greater capacity for homeostasis this marks a difference in the world of the living between, for example, cold-blooded and warm-blooded animals. The general point is that when a field of study is demarcated in accordance with a general property, if that property admits of significant variations those variations will make for differences within the originally delimited field.

Most every ethicist will agree that at its very outset ethics must distinguish human acts or knowing willing causings from nerve twitches. The point of disagreement will be whether knowing and willing generate differences in goodness and badness within the world of actions. If knowing and willing themselves did not admit of differences there would be one indisputable reason for holding that while knowing and willing do make actions actions they do not make actions good or bad. For if knowledge and volition do not admit of differences, they offer no further differences to make a difference in act evaluations. If these mental states admit only of breadth and extension and not of depth and intensity, then once over the threshold of morality, the voluntary, which these states constitute, we could put a consideration of such states to the side and look for the features in 
accordance with which one differentiated actions from one another as good or bad and better or worse. On the other hand, if knowing and willing themselves admit of differences, then these differences are differences in terms of which acts may be partially delimited as good or bad and better or worse in conjunction with the good or bad states of affairs agents cause by acting.

Clearly, willing itself admits of differences. For example, the difference between willing something in and for itself as one's end and willing something for the sake of something else, as a means. Since willing is one of the two phenomena, the other being knowing, in terms of which the good and bad effects of actions establish the goodness and badness of acts, it seems reasonable to hold that the differences of which willing admits constitute differences in act- evaluation. ${ }^{\mathrm{xv}}$

In fact, intending harm as an end is thought to differ in an ethically important way both from intending harm as a means and from foreseeing but not intending harm as a means or end. Thinkers on both sides of the debate concerning the ethical import of the $\mathrm{i} / \mathrm{f}$ distinction agree on this point. For example, opponents such as Jonathan Bennett and Judith Lichtenberg hold that intending harm as an end in itself importantly differs from intending harm as a means to some end. For example, Bennett asserts:

There is great moral significance in what a person intends as his end, what he pursues for its own sake; but that is irrelevant to our topic. Neither the terror nor the tactical bomber seeks or values civilian deaths for their own sake; each may regard them as deplorable -- something he would not bring about if it were detachable from his hastening of victory in this just war (Bennett, 1995, p. 215). ${ }^{\mathrm{xvi}}$

Bennett is correct. There is great moral significance in what a person intends as his end or for its own sake. Proponents and opponents of the distinction's ethical significance agree that intending what is bad as an end is ethically wrong because evil is to be avoided, not sought for its own sake. The disagreement concerns willing harm as a means to some good end in contrast to voluntarily causing 
the same harm without intent.

Yet, the reason for distinguishing acts in which one intends harm as an end from acts in which one either intends harm as a means or foresees but does not intend harm also grounds arguments for distinguishing acts in which one intends harm as a means from acts in which one foresees but does not intend harm. Take an hypothetical morality which primarily opposes the causing of pain. Willing can be related to causing pain in the following ways. 1)Pain can be willed as an end, for example, if a dentist sought to cause you pain for its own sake. 2)Pain can be willed for the sake of something else, as a means, for example, if a dentist caused you pain in order to punish you for not brushing your teeth or for bad breath. 3)Pain can be willed as an end and as a means, for example, if the dentist causes you pain in order to punish you and just for the sake of causing you pain. 4)Pain can be willed as a foreseen side-effect which is not wanted either for its own sake or for the sake of something else, but which one would rather cause than forgo what one does will for its own sake or for the sake of something else, for example, when a dentist drills a tooth without pain medication to which you are allergic. $^{\text {xvii }}$

In an ethics in which causing pain is to be avoided, causing pain just for the sake of causing pain is clearly the worst thing one can do. As we have seen, this point is not controverted in the debate concerning the $\mathrm{i} / \mathrm{f}$ distinction's ethical relevance. Yet, in the hypothetical ethic why would causing pain just for the sake of causing pain clearly be the worst thing one could do? This needs to be explained. By attending to the various ways in which the will can relate to pain, one can explain why willing it as one's end is the worst thing one can do. Because in terms of the intensity and depth of which willing admits, willing something for its own sake is the most complete way of willing something. Thus, to will for its own sake what is to be avoided is most intensely and most deeply wrong.

If an act that has pain as its end is, other things being equal, worse than an act that has pain as a means insofar as willing as an end is more intense than willing as a means, then there is also a 
relevant difference, other things being equal, between willing as a means and willing as a concomitant or side-effect of what one does will as an end or means. That is, just as willing harm as an end in itself is worse, other things being equal, than either willing harm as a means or willing harm as a side-effect, so too willing harm as a means is worse, other things being equal, than willing harm as a side-effect. This is precisely the point upon which the ethical relevance of the $\mathrm{i} / \mathrm{f}$ distinction depends.

Those who would argue that the difference between willing as a means and willing as a concomitant lacks ethical import face a significant problem. For they must explain the strongly held intuition that willing as an end differs from both willing as a means and willing as a concomitant in a way which does not ground distinguishing willing as a means from willing as a concomitant. On the other hand, those who hold the $\mathrm{i} / \mathrm{f}$ distinction to be ethically significant can explain its import in terms of the ethical relevance of volition. Such an account is consistent with the intuition that, other things being equal, willing harm as an end is worse than willing harm either as an end or as a means. Moreover, the account is in line with -- indeed follows from -- the very first distinction of any recognizable ethics, namely, that it is what one knowingly willingly causes with which ethics concerns itself.

Good and bad states of affairs lack ethical relevance in themselves. They acquire moral significance from being knowingly and willingly caused by human beings. So, for example, if a rock falls on you, this is bad, but not ethically bad or wrong. But, if you are harmless and I voluntarily throw it at you, this has ethical significance and is ethically bad or wrong. How could whether a good or bad state of affairs is knowingly willingly caused make all of the difference morally while further differences of which willing admits make no difference at all to the evaluation of actions? Such a position does not make sense. It is out of step with the very first distinction in any ethics -- that between what is and what is not voluntarily caused. This fundamental distinction indicates the grounds for holding that, other things being equal, there are important ethical differences between 
acts in which harm is willed as an end, acts in which harm is willed as a means, and acts in which harm is willed as a concomitant of what is willed as an end or means. Insofar as DER depends upon there being an ethically significant difference between the willing of harm as a means and the willing of harm as a foreseen concomitant, it rests on firm philosophical ground.

\section{NOTES}

i.Henceforth I will use the phrase 'double-effect reasoning' (DER) to refer to what has been called, most commonly, the 'Principle of Double Effect', the 'Doctrine of Double Effect' (Quinn, 1989), and the 'Rule of Double Effect' (Ramsey, 1978). There are a number of reasons to do so. First, it is not a principle, but, principally, two criteria. Second, its proponents and opponents sometimes reduce it to one criterion (the i/f distinction). This reduction is reinforced by the appellation 'Principle'. 'Doctrine' connotes an authoritative teaching; this is less accurate and more confusing than 'Principle' insofar as DER stands on firm philosophical ground. ii.See, for example, Jeff McMahan (1994); Joseph Boyle, (1980); and Elizabeth Anscombe, (1970). These theorists understand the i/f distinction to be ethically relevant in itself. As McMahan notes, however, Warren Quinn (1989) proposes an account of DER in which the i/f distinction does not have ethical importance in itself, but only in conjunction with another's right (McMahan, 1994, p. 206).

iii.In contemporary discussions, DER is usually applied to cases in which the harm is foreseen as an inevitable concomitant of realizing the intended end. If such an act were accounted ethically in the clear, a fortiori, so would an act similar in all respects, but for its causing harm without inevitability.

iv.On bombing, see, for example, McMahan (1995); on death-causing palliative analgesic administration, see, for example, Cavanaugh (1996a); on hysterectomy, see, for example, O'Donnell (1991). v.Traditionally, DER theorists are absolutists. However, some nonabsolutists have presented and defended revised versions of DER. DER theorists such as Boyle and Anscombe understand terror bombing always to be ethically out of bounds. Revisionist theorists such as McMahan and Quinn, speak in terms of there being a "stronger moral presumption" against terror bombing than there is against tactical bombing. By so speaking, they appear to hold that terror bombing is for the most part ethically out of bounds, but not necessarily

absolutely out of bounds. Of course, logically, one could hold that there is an absolute moral presumption against terror bombing while asserting that there is a stronger moral presumption against it than there is against tactical bombing. For a criticism of the revisionist 
use of DER, see Boyle (1991).

vi.DER is not based exclusively on the i/f distinction. Some prominent critics of DER do not acknowledge this point sufficiently. For example, Alan Donagan asserts that DER is simply a distinction between what one intends and what one does not intend (Donagan, 1977, p. 122 and p. 164.) If this were the case, a second condition for DER would be otiose. Yet, there is, generally speaking, one other condition of DER which DER theorists present either in a deontological or in a consequentialist form. Some theorists hold that the agent must have as great an obligation (or a greater obligation) to realize the good end as (or than) he has to avoid causing the bad effect while other DER theorists hold either that the agent must cause as much good as harm or greater good than harm. However DER theorists articulate the second condition, they do not propose the first condition as sufficient for judging an action which is good but for its causing harm to be ethically in the clear.

vii.Jonathan Bennett (1995) follows Lichtenberg (1994) in holding that the i/f distinction, although not ethically important in itself, may be associated with this ethically important difference in the probabilities of intended and foreseen consequences.

viii.There are good reasons to think that Aquinas, in his discussion of a private individual's act of homicidal self-defense -- Summa theologiae IIaIIae, $9.64, a .7$ the locus classicus of double effect -- had something like risking death in mind. On this point, see Cavanaugh, forthcoming.

ix.For a more detailed criticism of this -- mistaken -- interpretation of the i/f distinction, see Dean Cocking and Justin Oakley, 1994. x.Lichtenberg asserts:

I agree that the tactical bomber doesn't intend to kill civilians; the question is rather whether he is as responsible or answerable for these consequences as if he did. I acknowledge the conceptual difference; the question is whether or not this makes a moral

difference. (Lichtenberg, 1994, p. 367, note 16, emphases added) For a consideration of and response to Lichtenberg's criticism of double effect, see Cavanaugh (1996b).

xi.of course, although it is not attended to in most discussions of the i/f distinction's ethical relevance, the distinction applies to actions which bring about good and no harm. For example, in accordance with the i/f distinction, one contrasts an act in which an agent intentionally causes some good with an act in which an agent foreseeably but not intentionally causes the same amount of good with the same degree of probability. I owe this point to a conversation with David O'Connor of the University of Notre Dame.

xii.For other articulations of the distinction's ethical relevance, see Garcia (1993) and Cavanaugh, (1996b).

xiii. 'Willingly' is ambiguous between rational desire and affective 
desire. Affective desire for some outcome would be gladness that it came about. Rational desire is the apprehension of some upshot as being good and choiceworthy. One can rationally desire some outcome as an end, as a means to something else, or as a side-effect which one would rather bring about than forgo what one apprehends as being good in itself. It is possible that one not affectively desire what one rationally desires. For example, one may rationally, yet not affectively desire to pay one's rent or mortgage. Similarly, one may affectively desire what one does not rationally desire. For example, one may be glad at a sunny day, yet one does not rationally desire it insofar as we cannot cause sunny days. As I use the term, I mean 'willingly' to refer to rational desire. For a consideration of the ambiguity between affective and rational desire and the confusion it can cause in discussions of DER, see Finnis, 1991.

xiv.I understand knowing willing causing to include what one causes in culpable ignorance and what one causes by omission.

$\mathrm{xv}$.The cases contrasted in discussions of the i/f distinction and DER do not involve differences in knowledge. Accordingly, I will not discuss variations in epistemic states.

xvi.For a similar position, see Lichtenberg, 1994, p. 354. xvii.Other ways in which one's will could relate to pain would be: 5) not willing not to cause pain, for example, when a dentist does not bother to try not to cause pain and 6) willing not to cause pain, for example, when the dentist actually tries not to cause pain by administering novocaine.

\section{REFERENCES}

Anscombe, Elizabeth (1970) "War and Murder," In:Wasserstrom, Richard (ed) War and Morality (Belmont,Ca:Wadsworth).

Aquinas, Thomas (1962) Summa theologiae (Roma:Editiones Paulinae).

Bennett, Jonathan (1995) The Act Itself (Oxford:Clarendon Press).

Boyle, Joseph (1991) "Who is Entitled to Double Effect?" Journal of Medicine and Philosophy, $16: 475-494$.

(1980) "Toward Understanding the Principle of Double Effect," Ethics 90:527-538.

Cavanaugh, Thomas (1996a) "The Ethics of Death-Hastening or Death-Causing Palliative Analgesic Administration to the Terminally Ill," The Journal of Pain and Symptom Management, Vol. 12, No. 4, 1-7. 
(1996b) "The Intended/Foreseen Distinction's Ethical Relevance", Philosophical Papers, Vol. XXV, No.3.

(forthcoming) "Aquinas's Account of Double Effect," The Thomist.

Donagan, Alan (1977) The Theory of Morality (Chicago:Chicago University Press).

Finnis, John (1991) "Intention and Side-Effects," in Liability and Responsibility, ed. by Frey, R.G., and Morris, C.W., Cambridge:Cambridge University Press., pp. 32-64.

Garcia, Jorge L.A. (1993) "The New Critique of Anti-Consequentialist Theory," Philosophical Studies 71:1-32.

Lichtenberg, Judith (1994) "War, Innocence, and the Doctrine of Double Effect," Philosophical Studies 74:347-368.

McMahan, Jeff (1994) "Revising the Doctrine of Double Effect," Journal of Applied Philosophy 11: $201-212$.

Oakley, Justin and Cocking, Dean (1994) "Consequentialism, Moral Responsibility, and the Intention/Foresight Distinction," Utilitas 6: 201-216.

O'Donnell, Thomas J., S.J. (1991) Medicine and Christian Morality, New York:Alba House.

Quinn, Warren (1989) "Actions, Intentions, and Consequences: The Doctrine of Double Effect," Philosophy and Public Affairs 18:334-351.

Ramsey, Paul (1978) "Incommensurability and Indeterminacy in Moral Choice", in Doing Evil to Achieve Good; Moral Choice in Conflict Situations. ed. by McCormick, R.A., S.J., and Ramsey, P. Chicago:Loyola University 